\title{
Idea družstevníctva zo spoločenskovednej perspektívy so zvláštnym dôrazom na katolícku sociálnu náuku'
} Marián Sekerák

Úvod

Globálna kapitalistická ekonomika čelí mnohým závažným problémom. Adekvátny proces riešenia týchto problémov je preto nevyhnutný. Mainstreamový prístup reprezentovaný medzinárodnými inštitúciami má sklon poskytovat radikálne riešenia, aké presadzoval napríklad Medzinárodný menový fond $\mathrm{v}$ prípade gréckych ekonomických problémov: rozsiahle škrty vo verejných financiách, programy úspor v sociálnych službách a extenzívna privatizácia. ${ }^{2} \mathrm{Na}$ druhej strane, čoraz viac hlasov odborníkov zaznieva $\mathrm{v}$ prospech hladania akceptovatelných alternatív a inovatívnych prístupov nielen na mikro a makroekonomickej úrovni, ${ }^{3}$ ale aj v oblasti vládnutia. ${ }^{4}$ Niektorí dalšś akademici idú ešte dalej a volajú po tom, aby sme sa obrátili „od dominantnej koncepcie trhovej spoločnosti smerom ku konceptu pluralitnej ekonomiky, teda ekonomiky, ktorá siaha za oblast trhu, aby tak v sebe zahrnula dalšie ekonomické koncepty ${ }^{\text {“5 }}$ a to aj napriek faktu, že v procese globalizácie „poháňanom neoliberálnou utópiou trhovej spoločnosti sa situácia javí byt obzvlášt náročná“ ${ }^{6}$

1 Tento text bol vytvorený v rámci Programu rozvoja vedných oblastí na Univerzite Karlovej v Prahe (PRVOUK), P17 Vědy o společnosti, politice a médiích ve výzvách doby, ktorý prebiehal na Inštitúte politologických štúdií Fakulty sociálnych vied Univerzity Karlovej v Prahe. Predchádzajúca verzia tohto textu bola prezentovaná na „Medzinárodnej vedeckej konferencii 170 rokov družstevného hnutia na Slovensku (25. 11. 2015, Bratislava). Rád by som podakoval dvom anonymným recenzentom za ich hodnotné a konštruktívne pripomienky a návrhy, ktoré výrazne prispeli ku skvalitneniu tohto textu. Tiež by som rád podakoval Jozefovi Klingovi za jazykovú korektúru anglickej verzie a editorke časopisu za jej trpezlivost’ v priebehu recenzného procesu.

2 Porov. Damien CAHILL, Beyond Neoliberalism? Crisis and the Prospects for Progressive Alternatives, New Political Science 4/2011, s. 480.

3 L'uboš BLAHA, Ekonomická demokracia: nádej pre budúcnost'? in: Svet v bode obratu. Systémové alternatívy kapitalizmu. Koncepcie, stratégie, utopia, eds. Peter DINUŠ - Ladislav HOHOŠ, Bratislava: Veda - Ústav politických vied SAV, 2011, s. 70-103; Marián SEKERÁK, Zamestnanecká participácia ako inovatívny prístup v riadení podniku, in: Podnikanie v konkurenčnom prostredí. Zborník príspevkov $z$ vedeckého seminára, Komárno: Ekonomická fakulta Univerzity J. Selyeho v Komárne, 2012, s. 138-146; Naděžda JOHANISOVÁ - Stephan WOLF, Economic democracy: A path for the future?, Futures 6/2012, s. 562-570; Naděžda JOHANISOVÁ, Alternativy podnikání v nerůstové ekonomice, Acta Universitatis Carolinae - Philosophica et Historica. Studia Sociologica XIX 2/2013, s. 59-77; Wendy HARCOURT, The future of capitalism: a consideration of alternatives, Cambridge Journal of Economics 6/2014, s. $1307-1328$.

4 Michael PIRSON - Shann TURNBULL, Toward a More Humanistic Governance Model: Network Governance Structures, Journal of Business Ethics 1/2011, s. 101-114.

5 Jean-Louis LAVILLE, A New European Socioeconomic Perspective, Review of Social Economy 3/2003, s. 404.

6 Tamže. Pozri tiež Martin MURÁNSKY, Kapitalizmus a demokracia v čase európskej krízy, in: Kritická teória Jürgena Habermasa $v$ sociologickom výskume, ed. Miroslav TÍŽIK, Bratislava: Sociologický ústav SAV, 2013, s. 172-217. 
Takáto výzva sa zdá byt reakciou nielen na vy̌šie spomínanú krízu globalizovanej ekonomiky, ale súvisí tiež s protichodnou úlohou, akú zohráva národný štát. Štát je priamo „závislý od príjmov odvodzovaných od súkromného vlastníctva“, pričom sa tiež „štát na tieto príjmy spolieha. Konzekvencie vyplývajúce $\mathrm{z}$ tejto charakteristiky kapitalistického štátu poukazujú na výrazné vnútorné protirečenie. Na jednej strane štát musí podporovat proces akumulácie kapitálu a ochrany vlastníckych práv a na strane druhej, musí podporovat víziu štátu ako nestranného arbitra tried-

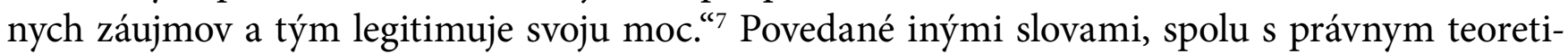
kom Jiřím Přibáňom: „Národné vlády sú slabé v tom, aby čelili globalizovaným ekonomickým mocenským štruktúram a súčasne sú čoraz viac a viac nenávidené a odmietané svojimi vlastnými občanmi, pretože sa cítia byt nedostatočne chránení proti asymetrickej globalizácii. ${ }^{\text {"8 }}$ Existuje tu však istá výnimka $\mathrm{z}$ tohto pravidla: ked premýšlame o alternatívnych ekonomických konceptoch, môžeme si spomenút na tie modely, ktoré boli už viac-menej overené v praxi. Medzi ne patrí právom aj idea družstevníctva, ktorá sa v ostatných rokoch čoraz častejšie (znovu)objavuje ako jeden $\mathrm{z}$ relevantných a autentických modelov.

Myšlienka družstevníctva je za ostatných viac než 20 rokov predmetom pomerne rozsiahleho odborného záujmu tak v slovenskom, ako aj v českom akademickom prostredí. Skúmaná je pomerne dôkladne $\mathrm{z}$ hladiska dejín ekonomického myslenia, ${ }^{9}$ histórie, ${ }^{10}$ práva $^{11}$ a v neposlednom rade aj ekonómie a manažmentu. ${ }^{12}$ Výrazne však $\mathrm{v}$ našom prostredí absentuje výskum družstevných ideí z pohladu sociálnej teórie.

Preto bude mojím cielom poskytnutie ucelenejšieho a systematickejšieho (hoci zaiste nie vyčerpávajúceho) obrazu o družstevníctve v sociálno-teoretickej perspektíve, so špeciálnym dôrazom na katolícku sociálnu náuku (dalej len KSN), a jej porovnaní s mainstreamovým prístupom, ktorý je reprezentovaný EÚ a OSN. V prvej časti predstavím základnú charakteristiku družstevného hnutia. Následne pristúpim k priblíženiu dvoch postáv tohto hnutia: jedného z jeho zakladatelov, utopického socialistu Roberta Owena a prvého revizionistu Marxovho učenia, Vladimíra Iljiča Lenina, ktorý sa tiež venoval družstevníctvu v jednom zo svojich menších spisov z prvej polovice

7 Branislav KOVÁČIK, Demokracia, korporatívny kapitalizmus a štát, Politické vedy 3-4/2008, s. 18.

8 Jiří PŘIBÁŇ, O bezmoci kritické teorie a expertního vědení v globální společnosti, in: Krize, nebo konec kapitalismu?, ed. Jiří PEHE, Praha: Prostor, 2012, s. 33.

9 Ilona BAŽANTOVÁ, Družstevní a svépomocné koncepce v českém ekonomickém myšlení, Praha: Prospektrum, 2002.

10 Gabriela KORIMOVÁ, Z dejín národného hospodárstva a ekonomického myslenia na Slovensku: Lesné družstevníctvo na Slovensku v rokoch 1918-1938, Ekonomický časopis 12/1995, s. 915-926; Roman HOLEC, 150 rokov slovenského družstevníctva. Vítazstvá a prehry, Bratislava: Družstevná únia Slovenskej republiky, 1995; Pavol MARTULIAK, Stopätdesiat rokov slovenského družstevníctva Nitra: Agroinštitút Nitra, 1995; Lidmila NĚMCOVÁ - Václav PRŮCHA, The Co-operative System in its Historical Perspecitve, in: Twelfth International Economic History Congress, Sevilla 1998. Session B 13. The Cooperative Movement in Historical Perspective - its Role, Forms and Economic, Social and Cultural Impact, ed. Lidmila NĚMCOVÁ, Praha: VŠE, 1998, s. 7-40; Adriana ŠVECOVÁ, Právne postavenie a činnost' potravných družstiev na príklade vybraných družstiev západného Slovenska v rokoch 1945-1952, Šamorín: Heuréka, 2011.

11 Ivana ŠTENGLOVÁ (ed.), Přehled judikatury ve věcech družstev, Praha: Aspi, 2004; Dana ZAPLETALOVÁ - Jiří TUZA, Odpovědnost družstva v obchodněprávních vztazích, Tábor: Jihočeská univerzita v Českých Budějovicích, 2005, s. 117-121; František HELEŠIC, Evropské a české družstevní právo, Praha: Eurolex Bohemia, 2006; Tomáš DVOŘÁK, Družstevní právo, 3. vyd., Praha: C.H. Beck, 2006; Juraj ŠPIRKO, Zodpovednost’ členov predstavenstva družstva, in: Vybrané otázky zodpovednosti za škodu spôsobenú nesprávnym profesijným postupom: všeobecná čast', Košice: Univerzita Pavla Jozefa Šafárika v Košiciach, 2010, s. 123-130; Karel ELIÁŠ - Jarmila POKORNÁ - Tomáš DVOŘÁK, Kurs obchodního práva. Obchodní společnosti a družstva, 6. vyd., Praha: C. H. Beck, 2010.

12 Jarmila LAZÍKOVÁ - Anna BANDLEROVÁ, Agricultural cooperatives in Slovakia, Studia Universitatis Babeş-Bolyai: Oeconomica 2/2007, s. 31-42; Jarmila LAZÍKOVÁ - Anna BANDLEROVÁ - Pavol SCHWARCZ, Agricultural cooperatives and their development after the transformation, Bulletin of Szent István University, Part II, 2008, s. 515-524; Halina STARZYCZNÁ, Spotřební družstevnictví a jeho pozice ve vnitřním obchodě ČR po roce 1989, Acta academica karviniensia, 1, 2009, s. 220-231; Elena ŠÚBERTOVÁ, Ekonomické a sociálne aspekty družstevného podnikania v SR, in: Marketing, manažment, obchod a sociálne aspekty podnikania. Zborník recenzovaných príspevkov z 2. ročníka medzinárodnej vedeckej konferencie, eds. Jana DZURIČKOVÁ - Barbora GONTKOVIČOVÁ, Bratislava: Ekonóm, 2014, s. 45-50. 
20. rokov minulého storočia. $\mathrm{V}$ dalšej časti osvetlím mainstreamový prístup $\mathrm{k}$ družstvám, ktorý predstavuje Medzinárodný rok družstiev, ktorý OSN vyhlásila pre rok 2012, ako aj správa Európskeho parlamentu z roku 2013. V porovnaní s týmito prístupmi ponúka KSN vlastné myšlienky o družstevníctve, a to vdaka náuke pápežov sv. Jána XXIII., sv. Jána Pavla II., Benedikta XVI. a Františka.

Predstavenie základných myšlienok týchto výrazných duchovných postáv 20., resp. 21. storočia vyústi do záveru o súčasnej role družstiev z pohladu KSN. Tento prístup predstavuje originálny príspevok $\mathrm{k}$ teórii družstevníctva a mohol by významne obohatit mainstreamový prístup.

\section{Hlavné črty družstevníctva}

Hoci sa termín „družstevníctvo“ zvykne viackrát stotožňovat s polnohospodárstvom, súčasné družstvá nie sú založené iba na polnohospodárskej báze. Mohli by sme vo všeobecnosti povedat', že družstvá „predstavujú zvláštny typ sociálno-ekonomických organizácií, ktoré sú združením - spolkom a zároveň hospodárskym subjektom - podnikom“. ${ }^{13}$ Sú často charakterizované aj ako „dobrovolné a otvorené spoločenstvá, demokraticky riadené, založené za účelom svojpomocného zaistovania hospodárskych, sociálnych alebo iných potrieb svojich členov" ${ }^{\prime 14}$ Rada EU ich opisuje ako „skupiny osôb alebo právne entity s osobitnými funkčnými princípmi, ktoré sú odlišné od iných ekonomických jednotiek. Tieto princípy zahŕňajú demokratickú štruktúru a kontrolu a distribúciu čistého zisku za účtovný rok na báze rovnosti. ${ }^{\text {“15 }}$

V širšom spoločenskom a politickom kontexte sa zvyknú považovat dokonca za akúsi „školu malej demokracie, školu drobného podnikania a rozvoja sociálneho kapitálu“. ${ }^{16} \mathrm{~V}$ najnovšom ekonomickom diskurze sa o nich už hovorí aj v súvislosti s tzv. hnutím nerastu, ekonomikou solidarity a inováciami prichádzajúcimi zdola. ${ }^{17}$ Vznik a rozvoj týchto „spolkov“, „podnikov“ či „škôl“", aby sme vymenovali aspoň niektoré charakteristiky, ktoré sú im prisudzované, však predpokladá existenciu a posilňovanie mentality eliminujúcej individualizmus, egoizmus a usilujúcej sa o spoluprácu, konsenzus a úsilie o spoločný prospech. Vskutku, ako pripomína napríklad Ratner, družstevníctvo vzniká v tej chvíli,

„ked’ sa jednotlivci začnú vzdávat’ svojho vykorenenia, súkromia a záujmu o seba samých a integrujú svoje bohatstvo, majetky a odmeny do demokraticky fungujúcej skupiny, v ktorej kolektívne rozhodujú, ako budú tieto zdroje použité na spoločný prospech (jej) členov. Členovia skupiny rozvíjajú skupinové projekty, identitu, pocity, potreby, motivácie, záujmy a zodpovednoste. Táto skupinová prax ústi následne do sociálnej solidarity a podpory jej (vlastných) členov. Ústi taktiež do aktívnej úlohy jednotlivých členov, ktorú zohrávajú vo formovaní aktivít skupiny, čo ovplyvňuje ich správanie." ${ }^{\text {18 }}$

13 KOLEKTÍV, Hospodářská demokracie v praxi. Jak funguje zaměstnanecká participace?, Praha: KSLP - Česká společnost pro zaměstnaneckou participaci, o. s., 2008, s. 95; kurzíva v origináli.

14 Tamže.

15 Council Regulation (EC) No 1435/2003 of 22 July 2003 on the Statute for a European Cooperative Society (SCE), článok 7.

16 Magdalena HUNČOVÁ, Ekonomický rozměr občanské společnosti, 2. vyd., Praha: Wolters Kluwer ČR, 2010, s. 215.

17 Pozri Naděžda JOHANISOVÁ - Ruben SURINACH PADILLA - Philippa PARRY, Co-operatives, in: Degrowth: A Vocabulary for a New Era, eds. Giacomo D’ALISA - Federico DEMARIA - Giorgos KALLIS, New York, Londýn: Routledge, 2015, s. 152-155.

18 Carl RATNER, Cooperativism: A Social, Economic, and Political Alternative to Capitalism, Capitalism Nature Socialism 2/2009, s. 55. 
Tieto psychologické aspekty stoja $\mathrm{v}$ základoch myšlienky družstevného podnikania. To sa premieta aj do družstevníckych zásad, resp. princípov, ako ich vymedzil Medzinárodný družstevný zväz (ICA). Napriek tomu, že „duch“ týchto princípov ostáva rovnaký už viac než 100 rokov, ich konkrétne znenie sa od 30. rokov minulého storočia viackrát menilo. To aktuálne pochádza z $\mathrm{r}$. 1995, kedy ich ICA na svojom zjazde v Manchestri schválil ich nasledujúcu podobu:

I. Dobrovolné a otvorené členstvo. Družstvá sú dobrovolnými organizáciami, otvorenými pre všetky osoby, ktoré môžu ich služby využívat’ a sú ochotné plnit svoje členské povinnosti bez diskriminácie pohlavia, spoločenskej, rasovej, politickej alebo náboženskej diskriminácie.

II. Demokratická členská kontrola. Družstvá sú demokratickými organizáciami kontrolovanými svojimi členmi, ktorí sa aktívne podielajú na plánovaní, prijímaní rozhodnutí a kontrole ich činnosti. Všetci členovia majú rovnaké hlasovacie práva na základe princípu jeden člen/členka - jeden hlas.

III. Ekonomická účast’ členov. Členovia družstva sa podielajú na tvorbe majetku družstva a kontrolujú jeho využívanie. Výhody z majetku plynú členom na základe práce, ktorú vykonali, nie na kapitáli, ktorý investovali.

IV. Autonómia a nezávislost. Družstvá sú autonómnymi a svojpomocnými organizáciami kontrolovanými vlastnými členmi. Ak družstvo vstupuje do zmluvných vztahov s inými organizáciami alebo získava kapitál z externých zdrojov, deje sa tak na základe dohôd zaručujúcich demokratickú kontrolu členmi družstva a udržiavajúcich autonómiu družstva.

V. Vzdelávanie, školenie a informácie. Družstvo zabezpečuje vzdelávanie a školenia svojim členom, voleným reprezentantom, manažérom a zamestnancom tak, aby čo najefektívnejšie prispievali k jeho rozvoju. Členovia družstva informujú širokú verejnost’ o povahe a výhodách družstiev.

VI. Spolupráca medzi družstvami. Družstvá slúžia svojim členom a prispievajú k efektívnemu posilňovaniu družstevného hnutia spolupracujúc s dalšími družstvami na miestnej, národnej, regionálnej a medzinárodnej úrovni.

VII. Spoluzodpovednost'za spoločnost'. Zameriavajúc sa na potreby svojich členov, družstvá pracujú na udržatelnom rozvoji spoločnosti prostredníctvom politík a programov akceptovaných ich členmi. ${ }^{19}$

\section{Tradícia Owena a Leninov „alternatívny pohlad“}

Zrod družstevného hnutia ako takého datujeme do 19. storočia, pričom jeho motiváciou bola potreba spolupráce v období priemyselnej revolúcie s meniacim sa spôsobom organizácie a del'by práce. Ludia prestali byt tými, ktorí vyrábajú veci, už viac neboli vlastníkmi svojich pracovných

19 (C) Cooperative identity, values and principles (on-line), dostupné na: http://ica.coop/en/whats-co-op/co-operative-identity-values-principles, citované 13. 1. 2016. 
nástrojov a nemali priamy zisk zo svojej práce. ${ }^{20}$ Boli to práve tieto rané formy kapitalizmu zamerané na zisk bez právnej či etickej regulácie, ktoré podnietili vznik družstevníctva.

Na počiatku družstevníckej tradície na území Slovenska stál „Gazdovský spolok v Sobotišti“, založený 9. februára 1845 Samuelom Jurkovičom. Tento spolok sa stal de facto prvým polnohospodárskym úverovým družstvom na európskom kontinente a vo svete. Bázou pre družstevnícke hnutie v Čechách bolo už v polovici 19. storočia pôsobenie lekára, politika a občianskeho aktivistu Františka Cyrila Kampelíka. Hnutie úverových družstiev v strednej Európe vznikalo v polovici 50. rokov 19. storočia a následne aj v 60. rokoch vd’aka práci nemeckých priekopníkov, ktorými boli Friedrich Wilhelm Raiffeisen a Franz Hermann Schulze-Delitzsch.

Za jedného z hlavných zakladatelov družstevníckeho hnutia (spolu s teoretikmi ako sú Ferdinand Lassalle, Louis Blanc a William Thompson) je považovaný Walesan Robert Owen, sociálny utopista, ktorý sa venoval produkcii bavlny vo vlastnej továrni. Na rozdiel od iných teoretikov utopického socializmu 18. storočia, akými boli napríklad Saint-Simon alebo Charles Fourier, považoval za príčinu všetkých nedostatkov kapitalizmu súkromné vlastníctvo, vykoristovanie námezdnej práce, náboženstvo a vtedajšiu podobu manželstva. Jeho sociálna filozofia bola inšpirovaná optimistickým pohladom na človeka. Veril, že charakter človeka môže byt' zlepšený vylepšením podmienok, v ktorých žije. Výrobňu považoval za základnú bunku, okolo ktorej by mala byt' vybudovaná spoločnost', pričom sama továreň by mala byt' manažovaná na družstevnom základe. Vyzdvihoval aj úlohu vzdelávania, napríklad aj tým, že v spoločnosti by nemali byt produkované len hmotné statky, ale výrobcom by malo byt' poskytované aj duchovné vzdelávanie. ${ }^{21}$

O viac než 100 rokov neskôr sa so zaostalými podmienkami obyvatel'stva vo vtedy čerstvo vzniknuvšom Sovietskom zväze, predovšetkým vidieckeho, usiloval bojovat', predovšetkým na teoretickej rovine, koryfej revolúcie a „teoretik smrti štátu“22 Vladimír Iljič Lenin. Svoje myšlienky o družstevníctve predložil v útlom a dodnes málo známom spise $O$ družstevníctve, ktorý napísal v januári 1923, a ktorý po prvýkrát vyšiel 26. a 27. mája 1923 v denníku Pravda (č. 115 a 116). ${ }^{23}$ Malá známost' toho spisu vyplýva aj z toho, že po nástupe Stalina k moci tento text „upadol do zabudnutia vnútri i mimo ZSSR“, a to aj napriek tomu, že predstavuje „zlomový bod v Leninovom politickom myslení“24 a možno ho považovat’ aj za znak jeho „intelektuálnej dospelosti“ ${ }^{25}$

Je plodom jeho úvah, ktorý zapadá do princípov Novej ekonomickej politiky (Novaja ekonomičeskaja politika, NEP) ako priamej reakcie na neúspešné protibol'ševické Kronstadtské povstanie $\mathrm{z}$ marca 1921. Bol to práve NEP, ktorý umožnil „štátny kapitalizmus“ a povolil súkromné podniky,

20 Porov. Ladislav FEIERABEND, Zemědělské družstevnictví v Československu do roku 1952, Volary: Stehlík, 2007, s. 11.

21 Porov. Ernesto SCREPANTI - Stefano ZAMAGNI, An Outline of the History of Economic Thought, 2. vyd., Oxford, NY: Oxford University Press, 2005, s. 139-140; Milan SOJKA, Dějiny ekonomických teorií, Praha: Havlíček Brain Team, 2010, s. 97. Viac o jeho myslení pozri Antonín PIMPER, Křestanský solidarismus, Praha: Č.A.T. - Universum, 1946, s. 27-30; Alexander BRÖSTL, Dejiny politického a právneho myslenia, Bratislava: Iura Edition, 1999, s. 194-196; Noel THOMPSON - Chris WILLIAMS, Robert Owen and his Legacy, Cardiff: University of Wales Press, 2011; Vladimír NAXERA - Ondřej STULÍK, Komparace sociálních utopií, Brno: Václav Klemm, 2012, s. 83-91; Nad’a JOHANISOVÁ, Ekonomičtí disidenti: kapitoly z historie alternativního ekonomického myšlení, Volary: Stehlík, 2014, s. 14-17; Pavel SIRU゚ČEK, Polozapomenuté postavy ekonomického myšlení - Robert Owen, Acta Oeconomica Pragensia 4/2015, s. $78-85$.

22 Bruno JOSSA, Marx, Lenin and the Cooperative Movement, Review of Political Economy 2/2014, s. 291.

23 Vladimír Iljič LENIN, O družstevnictví, Praha: Státní nakladatelství politické literatury, 1953. Anglická verzia: Vladimir Ilyich LENIN, Lenin's Collected Works, 2. anglické vyd., Moskva: Progress Publishers, Vol. XXXIII, 1965, s. 467-475; Robert C. TUCKER (ed.), The Lenin Anthology, New York: Norton, 1975.

24 Bruno JOSSA, Marx, Lenin and the Cooperative Movement, s. 286.

25 Op. cit., s. 292. 
vd’aka čomu sa stabilizovala ekonomika, stimuloval priemysel a polnohospodárstvo, pričom to už nebola vláda, ktorá by priamo direktívne stanovovala ceny tovarov a služieb. NEP a s ním súvisiace myšlienky o družstevníctve boli pragmatickým uznaním ekonomickej i politickej reality, hoci stále takticky vsadené do socialistického ideologického rámca. ${ }^{26}$

V spomínanom texte považuje Lenin družstevný systém za ideálnu cestu k socializmu pre drobných rolníkov, vdaka ktorému sa urýchli vývoj hospodárstva, civilizačný proces i lud sa kultúrne povznesie. ${ }^{27}$ Podla Lenina vo fáze nasledujúcej bezprostredne po proletárskej revolúcii, ktorá mala naštartovat budovanie socializmu smerom ku komunistickej spoločnosti, sa ešte treba spolahnút na trhy a družstvá a na istý čas odsunút proces ekonomického plánovania. ${ }^{28}$ Družstvá mali v tomto prechodnom type hospodárstva napomôct' dosiahnut socializmus a zabránit byrokratizácii komunistickej strany. ${ }^{29}$ Ich ekonomický zmysel bol teda čisto pragmatický a de facto zredukovaný na politickú rovinu. Prostredníctvom proletárskej revolúcie a následnej kolektivizácie výrobných prostriedkov, ako komentuje marxistickú a leninskú koncepciu Benedikt XVI. v jednej zo svojich encyklík, malo zrazu všetko íst iným a lepším spôsobom, avšak tento sen sa napokon rozplynul. ${ }^{30}$ nepomohla mu ani implantácia družstevníckych ideí. Na druhej strane, zamestnaneckú kontrolu a spolurozhodovanie $\mathrm{v}$ družstvách $\mathrm{v}$ zmysle zásad ekonomickej demokracie (t. j. zamestnaneckej participácie) Lenin odmietal, pretože takýto projekt považoval za „syndikalistický“. ${ }^{31}$

Lenin počítal so štátnou podporou družstiev ako s jednou z ciest budovania socializmu: „Družstvá musia byt politicky organizované takým spôsobom, že budú všeobecne a vždy nielen využívat isté úlavy, ale aby tieto úlavy mali čisto materiálny charakter (výška bankového úroku a podobne). Je potrebné poskytovat zo štátnych prostriedkov družstvám pôžičky, ktoré požičia-

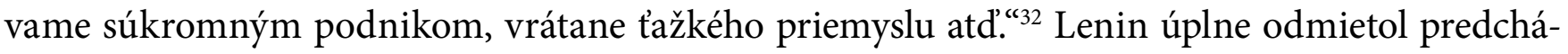
dzajúce myšlienky družstevného hnutia prezentované Owenom a považoval ich za „fantastické,

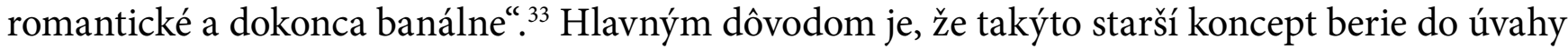
mierovú transformáciu „triednych nepriatelov do podoby triednych spolupracovníkov (...) obyčajným zdruštevnením obyvatelstva““ ${ }^{34} \mathrm{Na}$ druhej strane, Lenin tvrdil, že „bez triedneho boja za politickú moc $\mathrm{v}$ štáte nemôže byt’ socializmus uskutočnený “ ${ }^{35}$ Následne ako jeden $\mathrm{z}$ hlavných cielov revolučných socialistov považuje kultúrnu prácu medzi rolníkmi, pričom ekonomickým nástrojom tejto práce malo byt družstevníctvo. ${ }^{36}$

26 Viac o Leninovom politickom myslení pozri napr. Peter KULAŠIK - František BRIŠKA - Daniela JEŽOVICOVÁ, Dejiny politických teórii: Od staroveku do súčasnosti, Banská Bystrica: FPVaMV UMB v Banskej Bystrici, 2003, s. 154-157; Neil HARDING, Lenin's Political Thought: Theory and Practice in theDemocratic and Socialist Revolutions, Chicago, IL: Haymarket Books, 2009 [1977, 1978]. O NEP pozri viac napr. Roger William PETHYBRIDGE, One Step Backwards, Two Steps Forward: Soviet Society and Politics in the New Economic Policy, Oxford: Clarendon Press, 1990; Efim Gilevič GIMPELSON, NEP: Novaja ekonomičeskaja politika Lenina - Stalina. Problemy i uroki (20-e gody XX veka), Moskva: Sobranie, 2004; Robert PAVLOUŠEK, NEP jako pokus o tržní ekonomiku (Diploma thesis), Brno: Právnická fakulta Masarykovej univerzity v Brne, 2007; Lukáš VALEŠ, JZD Agrokombinát Slušovice - an example of efficiency in inefficient times, Scientia et Societas 4/2015, s. 114-115.

27 Porov. Lidmila NĚMCOVÁ - Václav PRŮCHA, K dějinám družstevnictví ve světě a v Československu, s. 23.

28 Porov. Bruno JOSSA, Marx, Lenin and the Cooperative Movement, s. 288.

29 Op. cit., s. 291.

30 Porov. BENEDIKT XVI., Deus caritas est, Trnava: Spolok svätého Vojtecha, 2006, $\$ 27$. Vtedajšiu českú akademickú kritiku socializmu z katolíckych pozícií predstavuje Alfred FUCHS, Demokracie a encykliky, Praha: Vyšehrad, 1936, s. 33-37.

31 Charles E. LINDBLOM, Politics and Markets: The World's Political-Economic Systems, New York: Basic Books, 1977 , s. 338.

32 Vladimír Iljič LENIN, O družstevnictví, s. 7.

33 Op. cit., s. 11.

34 Tamže.

35 Tamže.

36 Pozri op. cit., s. 12. 


\section{Mainstreamový prístup k družstevníctvu}

Odrazom svetových iniciatív usilujúcich o rozširovanie myšlienok družstevníctva bol Medzinárodný rok družstiev, za ktorý OSN označila rok 2012, pričom jeho motto znelo: Družstevné podniky budujú lepší svet. Medzinárodný rok sa začal na 66. plenárnom zasadaní Valného zhromaždenia OSN 31. októbra 2011. Ešte predtým, 64. VZ OSN schválilo 18. decembra 2009 rezolúciu A/ RES/64/136, ktorou sa uznieslo na vyhlásení spomínaného tematického roku. Touto rezolúciou OSN opätovne vyjadrila svoju dlhoročnú podporu družstevníckym myšlienkam.

V dokumente Valné zhromaždenie OSN rozpoznáva a uznáva, že „družstvá vo svojich rôznych podobách napomáhajú čo najplnšej možnej spoluúčasti na ekonomickom a sociálnom rozvoji všetkých ludí, vrátane žien, mladých, starších osôb, osôb s handicapom i domorodého obyvatelstva, pričom sa zároveň stávajú hlavným faktorom ekonomického a sociálneho rozvoja a prispievajú tak k eliminácii chudoby ${ }^{\text {“ }}{ }^{37}$ Jednou zo slabín takýchto vyhlásení vychádzajúcich z mainstreamového modelu je o. i. aj to, že neakcentujú environmentálne a spoločenské dimenzie družstevníctva.

Vyhlásením Medzinárodného roku družstiev sledovala OSN najmä tri ciele: podporovat rozvoj družstiev, zlepšovat' legislatívne podmienky pre ich existenciu a pôsobenie a zvyšovat̉ o nich povedomie širokej verejnosti. V samotnej rezolúcii napokon VZ OSN priamo vyzvalo vlády členských štátov, aby venovali pozornost̉ odporúčaniam Generálneho sekretariátu, týkajúcich sa propagácie rastu družstevných foriem podnikania, ako aj aby vytvárali priaznivé legislatívne a administratívne podmienky pre družstevné ekonomické aktivity vo svojich štátoch. Výzva bola smerovaná aj na oblast úzkej spolupráce vlád s národnými a medzinárodnými organizáciami zaoberajúcimi sa rozvojom a propagáciou družstevného podnikania.

Iniciatíva OSN z roku 2009 plynule nadväzuje na dlhodobú podporu družstevníckych ideí tejto medzinárodnej organizácie. Počas Druhej dekády rozvoja 1970-1980 OSN pripísalo družstevníctvu klúčový význam pri riešení problémov tzv. tretieho sveta. Rezolúcia Valného zhromaždenia OSN č. 64/136 zapadá do línie predchádzajúcich rezolúcií zo 60. i 70. rokov 20. storočia, ktoré venovali rozvíjaniu myšlienok družstevného hnutia značnú pozornost..$^{38}$

Na európskej úrovni sa družstevníctvu dostalo uznania o rok na to zo strany Európskeho parlamentu (EP), ktorý 30. 5. 2013 prijal Správu o príspevku družstiev k prekonávaniu krízy (2012/2321[INI]) datovanú 12. 6. 2013. Prijatá bola na základe hlasovania vo Výbore pre priemysel, výskum a energiu (spravodajkyňou bola europoslankyňa Patrizia Toia z Aliancie liberálov a demokratov za Európu). V tejto voči družstevníctvu vysoko pozitívne ladenej správe, pozostávajúcej z 51 bodov EP o. i. konštatuje, že

„družstvá, spoločne s dalšími podnikmi sociálnej ekonomiky, zohrávajú zásadnú úlohu v európskej ekonomiky zvlášt v časoch krízy tým, že kombinujú ziskovost’ so solidaritou, vytvárajú vysoko kvalitné pracovné miesta, posilňujú spoločenskú, ekonomickú a regionálnu súdržnost a vytvárajú sociálny kapitál“", ${ }^{39}$ pričom, „model družstevného podnikania prispieva k reálnemu ekonomickému pluralizmu je súčastou ,sociálnej trhovej ekonomiky““. ${ }^{40}$

37 Rezolúcia Valného zhromaždenia OSN č. 64/136: Cooperatives in social development, 18. december 2009.

38 Pozri Lidmila NĚMCOVÁ - Václav PRŮCHA, K dějinám družstevnictví ve světě a v Československu, s. 11.

39 EURÓPSKY PARLAMENT, Report on the contribution of cooperatives to overcoming the crisis $(2012 / 2321[$ INI]), 12 . jún 2013 , $\$ 1$.

40 Op. cit., $\$ 3$. 
EP tiež vo svetle vtedy aktuálnej hospodárskej krízy a jej dôsledkov vyjadril názor, že „družstvá boli voči kríze viac imúnne vzhladom na svoj osobitný model riadenia, ktorý je založený na spoločnom vlastníctve, demokratickej ekonomickej participácii a kontrole, organizácii a manažmente prostredníctvom akcií jednotlivých členov, ako aj na záväzku voči spoločenstvu. " ${ }^{\text {"11 }} \mathrm{V}$ podstate tak EP explicitne spomína charakteristické črty, ktoré ako pozitívne vyzdvihujú v rámci KSN aj pápeži, ako bude priblížené nižšie.

\section{Pápeži o družstevníckom hnutí}

Hlavy katolíckej cirkvi, si už prinajmenšom od druhej polovice minulého storočia dobre uvedomujú nedostatky a hrozby kapitalistickej ekonomiky, ktoré kritizoval aj vyššie spomínaný Lenin. Aj preto odmietajú prijat’ neoliberálny model, ktorý mainstreamová ekonómia presadzuje už dlhodobo ako optimálny. ${ }^{42} \mathrm{Na}$ druhej strane, bolo by mylné tvrdit, že kritika kapitalizmu zo strany KSN automaticky znamená prijatie marxistických premís, ako ich postuloval V. I. Lenin.

Aj niekdajší kardinál Joseph Ratzinger (a neskorší pápež Benedikt XVI.) vo svojom opus magnum „Úvod do krestanstva“ zásadne rozlišuje medzi krestanstvom a marxizmom. Marxistický princíp síce spočíva na pozitívnej myšlienke nádeje, podobne ako krestanstvo so svojou vierou v Krista - Vykupitela, „keď̌e podla neho je trpiaci proletariát vykupitelom sveta“. ${ }^{43}$ Avšak toto utrpenie proletariátu „sa musí konkrétne realizovat v aktívnej forme triedneho boja. Iba tak sa môže stat’ ,vykupitel'ským' a viest' ku zneškodneniu vládnucej triedy a k rovnosti všetkých ludí. Ak je Ježišov kríž ,utrpením pre niekoho', tak utrpenie proletariátu je (...) bojom proti niekomu. Ak je kríž hlavne dielom jednotlivca v prospech celku, utrpenie proletárov je hlavne vecou masy organizovanej do strany. Napriek akejsi počiatočnej blízkosti sa napokon obe cesty rozbiehajú opačným smerom. ${ }^{\text {"44 }}$

Pápeži však neostávajú iba pri kritike kapitalizmu, ale podporujú aj funkčné alternatívy, akou je nepochybne aj družstevnícky typ podnikania. Nevychádzajú pritom, samozrejme, zo socialistickej ideológie ako Lenin, lež z katolíckej sociálnej náuky, o ktorej sa traduje, že jej korene siahajú prinajmenšom k encyklike Leva XIII. z roku $1891 .{ }^{45}$ Tá sa stala prvou sociálnou encyklikou, teda platným a záväzným dokumentom Magistéria zameraným na sociálne a ekonomické otázky.

Prvé letmé zmienky o družstevníctve nájdeme v encyklike sv. Jána XXIII. Mater et Magistra, konkrétne v čl. 72-77. V nich družstevné podnikanie pozitívne oceňuje, pričom vymenúva niekol'ko odporúčaní. Tieto typy podnikov by sa mali stále prispôsobovat’ novým situáciám plynúcim z pokroku vo vede a technike a tiež meniacim sa požiadavkám a záujmom spotrebitelov. Mali

41 Op. cit., $₫ 7$.

42 Pozri napríklad Marián SEKERÁK, Neoliberální ekonomická teorie a praxe a její recepce u sv. Jana Pavla II., Benedikta XVI. a Františka, Studia Theologica 1/2015, s. 108-132.

43 Jozef RATZINGER - BENEDIKT XVI., Úvod do krestanstva, Trnava: Dobrá kniha, 2007, s. 212.

44 Tamže. Lenina spomína Ratzinger aj o niekol'ko desatročí neskôr: ako pápež zmieňuje vo svojej encyklike Spe salvi slepú uličku marxizmu, t. j. absenciu nadväznosti spoločenského poriadku po úspešnej implementácii proletárskej revolúcie, čoho si bol Lenin sám dobre vedomý; Pozri BENEDIKT XVI., Spe salvi, Trnava: Spolok svätého Vojtecha, 2007, \$21. Taktiež právny teoretik A. Bröstl potvrdzuje pápežove slová vo svojom komentári Leninovho myslenia o štáte: „V predvečer dňa, ked siahne po moci, Lenin predpovedá dlhodobú diktatúru proletariátu, ale pripúšta, že nevie, ako dosiahnut vytýčený ciel', po rozbití byrokraticko-vojenského štátneho aparátu“; Alexander BRÖSTL, Dejiny politického a právneho myslenia, s. 247.

45 Porov. Lubomír MLČOCH, Analýza a interpretace současné katolické sociální nauky z pohledu ekonomie, in: Katolická sociální nauka a současná věda, eds. Petr FIALA - Jiř́i HANUŠ - Jan VYBÍRAL, Brno, Praha: CDK, Vyšehrad, 2004, s. 101. 
by sa tiež profesijne organizovat. Navyše by sa voči nim uplatňovala „primeraná hospodárska politika, najmä pokial ide o vzdelávanie, daňové zataženie, úvery a sociálne poistenie“. ${ }^{46}$ Pápež napokon svoje relatívne vágne a všeobecné formulácie uzatvára konštatovaním, že družstvá „sú nositelmi rýdzich ludských hodnôt a prispievajú k pokroku civilizácie“. ${ }^{47}$

Traja pápeži, ktorých pontifikát bol/je (sčasti alebo úplne) umiestnený v 21. storočí, teda sv. Ján Pavol II., Benedikt XVI. a František, využili na uvažovanie o družstvách príhovory vo Vatikáne, ktoré boli adresované rozličným družstevníckym organizáciám a zoskupeniam. Každý z nich sa pritom odvolal na hodnoty a myšlienky, ktoré predložil Lev XIII. v už spomínanom dokumente Rerum novarum. Svoje myšlienky odvodzovali, celkom prirodzene, aj od II. vatikánskeho koncilu a jeho záverov, hoci tento sa o družstevníctve - opät z pomerne pochopitelných dôvodov - vyjadril len velmi skromne. Marginálnu zmienku môžeme nájst' v podstate len $\mathrm{v}$ jedinom koncilovom dokumente, ktorým je Pastorálna konštitúcia o cirkvi v dnešnom svete Gaudium et Spes zo 7. decembra 1965. V nej konciloví otcovia uvádzajú nasledovné:

„Vzhladom na rôzne situácie sa vyžadujú reformy zamerané na zvýšenie príjmov, zlepšenie pracovných podmienok, zväčšenie istoty zamestnania, podnecovanie osobnej iniciatívy, alebo aj rozdelenie nedostatočne obrábanej pôdy tým, ktorí ju budú vediet zužitkovat'. $\mathrm{V}$ tomto prípade im treba poskytnút potrebné vybavenie, zvlášt vzdelávanie a možnost' vhodnej družstevnej organizácie. ${ }^{{ }^{4} 8}$

V marci roku 1984 sa Ján Pavol II. prihovoril 3. národnému kongresu talianskej družstevnej federácie. V ňom, odvolávajúc sa na katolícku sociálnu náuku, okrem iného upozornil, že „solidarita a ludský rast videný $\mathrm{v}$ jeho komplexnosti, teda z ekonomického, spoločenského a ludského hladiska, je chrbtovou kostou systému družstevných združení“ ${ }^{49}$ Zároveň zdôraznil, súc si vedomý zásad a princípov družstevníctva, že družstvo musí vyvažovat potreby svojich jednotlivých členov a sociálne služby. Konštatoval tiež, že napomáhanie vzájomného ludského rozvoja a integrácie prostredníctvom družstevného podnikania redukuje individualizmus a vyzdvihuje rôznorodost inštitúcií viacerých sektorov bez toho, aby bola ohrozená ich identita.

O niekolko rokov nato, v júni 1998, sa pontifik z Polska prihovoril vo Vatikáne Centrálnemu inštitútu talianskych družstevných úverových bánk (tal. l'Istituto di credito delle casse rurali e artigiane). Pripomenul, že koncept tohto typu bánk je v talianskej spoločnosti zakorenený už viac než 100 rokov a predstavuje „podnetnú skúsenost participácie“ a „účinný nástroj pre získavanie vyššej úrovne spravodlivosti “. ${ }^{50}$ Zaujímavostou je, že z úst pápeža zaznelo v tejto súvislosti aj slovné spojenie „ekonomická demokracia“, ked” sa vyjadril, že aktivity družstevných úverových bánk napomáhajú „propagovat reálnu ekonomickú demokraciu s úrokom poskytovaným v primeranom rozsahu“. ${ }^{51}$ Toto vyzdvihovanie hospodárskej demokracie, teda zamestnaneckej participácie

46 Dokumenty sociálnej náuky cirkvi. Trnava: Spolok svätého Vojtecha, 2007. Encyklika Mater et Magistra, \$75 (online anglická verzia na Vatican.va, $\$ 88)$.

47 Op. cit., $\$ 76$ (online anglická verzia na Vatican.va, $\$ 89$ ).

48 Dokumenty II. vatikánského koncilu. Praha: Zvon - České katolické nakladatelství, 1995. Konštitúcia Gaudium et Spes, \$71.

49 @ JÁN PAVOL II., Discorso di Giovanni Paolo II ai partecipanti al III Congresso nazionale della Confederazione Cooperative Italiane, 30. 3. 1984 (on-line), dostupné na: https://w2.vatican.va/content/john-paul-ii/it/speeches/1984/march/documents/hf_jp-ii_ spe_19840330_congresso-confcooperative.html, citované 18. 11. 2015.

50 ๑ J JÁN PAVOL II., Address of the Holy Father Pope John Paul II to Central Institute of Co-operative Credit Banks, 26. 6. 1998 (on-line), dostupné na: https://w2.vatican.va/content/john-paul-ii/en/speeches/1998/june/documents/hf_jp-ii_spe_19980626_credito-cooperativo.html, citované 18. 11.2015.

51 Tamže. 
vo firme, v ktorej pracujú, nebolo ojedinelé, ako dokazujú rôzne iné zmienky o tomto koncepte, a to nielen u sv. Jána Pavla II. ${ }^{52}$

Podla pápeža Wojtyłu spočíva vel'ký význam družstiev aj v tom, že oceňujú rolu jednotlivca v spoločnosti a zároveň ochraňujú legitímne záujmy osoby. Štruktúra družstevných úverových bánk ako takých „je založená na spoločenstve osôb, nie na kapitáli“, čo znamená - opät v súlade s družstevnými princípmi -, že „hlavným cielom nie je zisk, ale uspokojovanie sociálnych potrieb“. ${ }^{3}$

Podobnú rétoriku použil v decembri roku 2011 aj Benedikt XVI. vo svojom príhovore k členom Konfederácie talianskych družstiev a Talianskej federácie družstevných úverových bánk. Aj on pripomenul, že v širších dimenziách

„oporný bod družstevníckej skúsenosti spočíva presne v záväzku uviest’ do súladu dimenzie jednotlivca a spoločnosti. Je praktickým výrazom komplementarity a subsidiarity, ktorú cirkevné sociálne učenie vždy podporovalo medzi osobami a štátom. Je to rovnováha medzi ochranou práv jednotlivca a propagovaním spoločného dobra $\mathrm{v}$ úsilí rozvíjat miestnu ekonomiku, ktorá reaguje viac a viac na potreby skupiny. $\mathrm{Na}$ etickej úrovni je tiež rovnako typická citlivostou $\mathrm{k}$ solidarite a rešpektom voči spravodlivej autonómii jednotlivca." ${ }^{\text {"54 }}$

V jeho prejave, o čosi viac než v prípade jeho svätého predchodcu, sú zjavné odvolávky na krestanstvo a Boha. Benedikt XVI. totiž vyzval členov združení, ku ktorým prehovoril, aby pamätali na to, čo charakterizuje krestanské družstvá. Vyzval ich tiež, aby ostali verní evanjeliu a cirkevnému učeniu.

V značne odlišnom duchu sa niesol prejav pápeža Františka z februára 2015. Aj on sa prihovoril zástupcom a zástupkyniam Konfederácie talianskych družstiev, avšak jeho rétorika sa podstatne liši od tej, ktorá bola typická pre jeho dvoch predchodcov. Zatial čo myšlienky sv. Jána Pavla II. a Benedikta XVI. boli charakteristické svojou uhladenostou, formálnostou a všeobecnostou pokial' ide o samotnú problematiku družstevníctva, Františkove slová sú vel’mi adresné, konkrétne a vychádzajúce priamo z jeho osobných, explicitne vyjadrených sympatií s družstevným typom podnikania.

Z jeho prejavu možno vyzdvihnút niekol'ko rovín, ktoré ponúka, resp. otvára. Predovšetkým si pápež všíma neutešujúcu situáciu mnohých ludí v súčasnej spoločnosti vyspelých kapitalistických štátoch. Upozorňuje najmä na problém nezamestnanosti a slabo platenej práce: „Je dnes bežné, nehovorím normálne, ale štandardné (...), že často niekto vidí ,Hladáš si prácu? Pod’, príd’ do našej firmý. Jedenást' hodín práce, $600 €$. ,Páči sa ti to? Nie? Tak chod’ domov,““ opísal František ${ }^{55}$ tvrdú realitu na tzv. trhu práce, aj to s ešte príliš optimistickým videním mzdových podmienok a opýtal

52 Pozri Marián SEKERÁK, Ekonomická demokracia: Dejiny, teória a prax, Banská Bystrica: FPVaMV UMB v Banskej Bystrici, 2013, s $70-79$.

53 @ JÁN PAVOL II., Address of the Holy Father Pope John Paul II to Central Institute of Co-operative Credit Banks.

54 ( ) BENEDIKT XVI., Address of His Holiness Benedict XVI to Members of the Confederation of Italian Cooperatives and of the Italian Federation of Cooperative Credit Banks, 10. 12. 2011 (on-line), dostupné na: https://w2.vatican.va/content/benedict-xvi/en/speeches/2011/december/documents/hf_ben-xvi_spe_20111210_cooperative.html, citované 8. 11. 2015.

55 () FRANTIŠEK, Address of His Holiness Pope Francis to representatives of the Confederation of Italian Cooperatives, 28. 02.2015 (on-line), dostupné na: http://w2.vatican.va/content/francesco/en/speeches/2015/february/documents/papa-francesco_20150228_confcooperative.html, citované 18. 11. 2015 . 
sa, čo treba robit vo svete, ktorý funguje takýmto spôsobom? Poukázal aj na vylučovanie osôb, ktoré sa pre svoj vek stretávajú s diskrimináciou v procese uchádzania sa o zamestnanie: „,Kto si?’ - ,Som inžinier.“ - ,Aha, tak to je pekné, veru pekné. Kol'ko máš rokov?` - ,49“ - ,Nie, Teba nepotrebujeme, chod' preč. 'Toto sa stáva dennodenne,“ opísal František plasticky. ${ }^{56}$ Úlohou družstiev je dnes podla neho čelit a bojovat práve s takouto „kultúrou odhadzovania,“ ktorú žijeme, kultúru zbavovania sa zdanlivo nepotrebných ludí, ale aj potravín a vecí,“ kultúru, ktorú, ktorá „podopiera ekonomické a finančné politiky globalizovaného sveta a $\mathrm{v}$ strede ktorej je boh peňazi““. ${ }^{57}$

Odvolávajúc sa na cirkevného Otca a učitela cirkvi zo 4. storočia sv. Bazila Vel'kého a na sv. Františka z Assisi pápež zopakoval, že „peniaze sú diablove výkaly“. Ak sa totiž peniaze stávajú modlou, sú to ony, ktoré rozhodujú o človeku, robia z neho svojho služobníka: „Peniaze v službe životu môžu byt๋ manažované spravodlivým spôsobom v družstvách ak (...) sú to autentické, skutočné družstvá, kde kapitál nie je pánom nad človekom a človek nad kapitálom. ${ }^{\text {"58 }}$

Podobne proti zbožštovaniu peňazí argumentoval aj vo svojej posynodálnej apoštolskej exhortácii Evangelii gaudium, v ktorej uviedol, že „pokojne prijímame ich vládu nad nami i nad našimi spoločnostami“ ${ }^{59} \mathrm{~V}$ tom istom dokumente pripomenul, že „[p]eniaze musia slúžit, nie panovat! “60

Z uvedených dôvodov pápež vyzval na boj s falošnými družstvami, ktoré „prostituujú skutočný význam slova družstvo, totiž skutočne dobrej organizácie za účelom balamutenia ludí s cielom ziskov, ktoré sú v rozpore s tými, ktoré sú typické pre skutočné a autentické družstvo". ${ }^{61}$ Autentické družstvá, o ktorých pápež hovoril, charakterizuje najmä to, že neexistujú primárne kvôli tomu, aby vytvárali zisk, ale aby zabezpečovali benefity pre všetkých svojich členov. Zatial' čo konvenčné podniky orientované na zisk „sú nútené tvorit’ ponuku vytváraním neraz falošných produktov alebo služieb, družstvá (...) dokážu lahšie uspokojovat skutočné potreby“. ${ }^{2}$ Ich typickou črtou je tiež rozšírenie oblasti pôsobnosti aj mimo ekonomickú sféru, napr. na oblast’ sociálnu či kultúrnu, s presahom pozitívnych externalít do ich komunity, miesta či regiónu pôsobenia. ${ }^{63}$

Zrejme aj preto sa niektorí akademici, ako napr. sociológ Charles Derber, domnievajú, že svojím participatívnym založením, tak v oblasti pracoviska ako aj širšej komunity, umožňujú družstvá „vyživovat’ občiansku spoločnost’ a ekonomický dynamizmus“. ${ }^{64}$ Miera akceptácie princípu vzájomnosti, na akom autentické družstvá fungujú, môže podla M. Hunčovej viest’ k dvom extrémnym situáciám. Po prvé k uzavretiu, „mumifikácii“ družstva do interného okruhu komunitnej autarkie; deje sa to v prípade absolútneho chápania princípu vzájomnosti. Po druhé - ak dôjde $\mathrm{k}$ atrofii tohto princípu - potláča sa členský princíp na úkor konkurencieschopnosti; v takom prípade stráca špecifická forma družstevného hospodárenia svoj raison d'être. ${ }^{65}$

\footnotetext{
56 Tamže.

57 Tamže.

58 Tamže.

59 FRANTIŠEK, Evangelii gaudium, Praha: Paulínky, 2014, § 55.

60 Op. cit., $\$ 58$.

61 (c) FRANTIŠEK, Address of His Holiness Pope Francis to representatives of the Confederation of Italian Cooperatives.

62 Naděžda JOHANISOVÁ - Stephan WOLF, Economic democracy: A path for the future?, s. 565.

63 Porov. Magdalena HUNČOVÁ, Ekonomický rozměr občanské společnosti, s. 221. Najnovšiu prípadovú štúdiu vzájomného vztahu medzi miestnym rozvojom a družstvami na príklade Peru ponúka Małgorzata KURJAŃSKA, A cooperative Peru: Is centralization of cooperatives better for local development?, Development in Practice 3/2015, s. 306-320.

64 Charles DERBER, If not Socialism, What?, Peace Review 1/1997, s. 104.

65 Porov. Magdalena HUNČOVÁ, Ekonomický rozměr občanské společnosti, s. 211.
} 
Druhou rovinou, akú František vo svojom príhovore otvoril, je globalizácia solidarity. To podla neho znamená „premýšlat o špirálovitom náraste počtu nezamestnaných ludí, o nekonečných slzách chudobných, o potrebách navrátit sa k rozvoju, ktorý je pravdivým, integrálnym procesom osoby, ktorá iste potrebuje príjem, ale nielen príjem! "'66 Družstvá by preto mali vykročit smerom k existenčným perifériám, kde sa musí znovu objavit nádej a kde súčasný sociálno-politický systém sa javí byt "„totálne odsúdený na to, aby zadusil nádej, ukradol nádej, zvýšil riziká a hrozby, ${ }^{\text {“67 }}$ čím mal zrejme na mysli rozličné nové sociálne riziká, ktorým je v kapitalistickej spoločnosti takmer nemožné sa vyhnút', zvlášt pokial ide o reprezentantov strednej triedy a tzv. underclass. ${ }^{68}$

Tretia rovina nastolená Františkom spočíva v niekolkých výzvach a povzbudeniach, ktoré ponúkol. Po prvé, družstvá musia pokračovat $\mathrm{v}$ tom, aby boli motorom pozdvihujúcim a rozvíjajúcim najslabšie časti miestnych komunít, kde pôsobia, ako aj celej občianskej spoločnosti. Obyčajný cit toho totiž podla neho nie je schopný. ${ }^{69}$ Druhým povzbudením, nie však z hladiska dôležitosti, je výzva, aby sa družstvá stali aktívnymi lídrami vo vytváraní nových riešení $\mathrm{v}$ oblasti blahobytu, zvláśt na poli zdravotnej starostlivosti.

Tretie povzbudenie sa týka ekonomiky a jej vztahu k sociálnej spravodlivosti, dôstojnosti a hodnote človeka: „Je dobre známe, že istý liberalizmus (tal. „un certo liberismo“) verí, že je nevyhnutné produkovat najskôr bohatstvo, pričom nezáleží na tom ako, a následne propagovat určité politiky redistribúcie zo strany štátu“.70

Štvrtý bod povzbudenia zhrnul pápež do výzvy pomáhat rozvoju, udržiavaniu a posilňovaniu rodinného života, kedže ekonomika sa nemôže rozvíjat', ked’ populácia starne a upadá, ale len ak rastie. Posledný, piaty bod povzbudenia pápež podla vlastných slov prekvapuje, pretože pripomína nevyhnutnost peňazí: „Vyžaduje si to peniaze - vykonat všetky tieto veci! Družstvá vo všeobecnosti nie sú založené na vel'kom kapitále, ale hovorí sa o nich prevažne ako o štrukturálne podkapitalizovaných. Namiesto toho vám pápež hovorí: musíte investovat a musíte investovat dobre!“71

K týmto piatim povzbudeniam pridal v septembri 2015 ešte dalšie dva, ktoré predstavil vo svojom príhovore k personálu rímskej Družstevnej úverovej banky. Šiestym jeho povzbudením pre družstvá v rade je teda výzva tvorit ekonomiku čestného rastu a to, paradoxne, „v časoch, kedy je korupcia všadeprítomná." Siedmou a poslednou je výzva „hrat aktívnu úlohu v globalizácii, aby sa tak solidarita globalizovala. “72 Podobne ku "globalizácii solidarity“ vyzýval František už skôr,

66 ๑ FRANTIŠEK, Address of His Holiness Pope Francis to representatives of the Confederation of Italian Cooperatives.

67 Tamže.

68 Pozri Jan KELLER, Nová sociální rizika a proč se jim nevyhneme, Praha: SLON, 2011.

69 Podobné úvahy prezentuje aj sociológ Derber, ktorý píše, že „družstevníctvo (...) úzko prepája ekonomickú zmenu a pretváranie občianskej spoločnosti“; Charles DERBER, If not Socialism, What?, s. 107.

70 @ FRANTIŠEK, Address of His Holiness Pope Francis to representatives of the Confederation of Italian Cooperatives. Pripomeňme, že podobným spôsobom v Evangelii gaudium pranieruje také ekonomické teórie, „ktoré tvrdia, že bohatnutie bohatých časom vytvorí blahobyt aj pre chudobných, a tiež teórie, ktoré predpokladajú, že ekonomický rast podporený volným trhom dokáže sám od seba vyprodukovat väčšiu rovnost’ a začlenenie ludí do spoločnosti vo svete. Tento názor, ktorý nikdy nebol potvrdený konkrétnymi faktami, je znakom neprezieravej a prostoduchej dôverčivosti v dobro tých, ktorí majú v rukách ekonomickú moc a „posvätné“ mechanizmy vládnuceho ekonomického poriadku. Vylúčení medzičasom stále čakajú “; FRANTIŠEK, Evangelii gaudium, \$54. Podobne píše aj vo svojej sociálnej encyklike Laudato Si’: „...je potrebné vyhnút sa magickému chápaniu trhu, ktoré má tendenciu si mysliet', že problémy sa vyriešia len rastom zisku podnikov alebo jednotlivcov“; FRANTIŠEK, Laudato Si’, Praha: Paulínky, 2015, \$ 190. Taktiež už spomínaný profesor Derber poukázal na istý paradox v prípade volného trhu. Všimol si, že trh pre svoju vlastnú existenciu potrebuje dôveru a solidaritu, ale svojím „náboženstvom sebectva osekáva všetky podoby spoločenskej solidarity“, čím vlastne volný trh „sabotuje podmienky svojho vlastného prežitia“; Charles DERBER, If not Socialism, What?, s. 100.

71 () FRANTIŠEK, Address of His Holiness Pope Francis to representatives of the Confederation of Italian Cooperatives.

72 ( ) FRANTIŠEK, Address of His Holiness Pope Francis to the personnel of the Cooperative Credit Bank of Rome, 12. 09. 2015 (on-line), 
vo svojom príhovore $\mathrm{k}$ účastníkom a účastníčkam Svetového kongresu účtovníkov v novembri 2014: „Ak chceme zanechat budúcim generáciám lepšie životné prostredie, ekonomické, kultúrne a spoločenské dedičstvo, ktoré sme sami dostali, sme povolaní uvedomit’ si vlastnú zodpovednost’ na práci na globalizácii solidarity. Solidarita je požiadavkou, ktorá vzrastá z tej istej siete prepojení, ktorá sa rozvíja spolu s globalizáciou."73

O potrebe „globalizácie solidarity“ však nehovoril len František, ale pred ním už aj jeho dvaja predchodcovia. Sv. Ján Pavol II. prispel k rozvoju tohto konceptu v rámci KSN svojím posolstvom k 17. Valnému zhromaždeniu Caritas Internationalis z júla 2003:

„Vskutku, ak sa má solidarita stat’ celosvetovou, musí brat do úvahy všetkých ludí zo všetkých regiónov sveta. (...) Globalizácia solidarity tiež znamená úzku spoluprácu a pevný vztah s medzinárodnými organizáciami, ktoré sú garantmi práv, aby sa tak vytvorila nová rovnováha vo vztahu medzi bohatými a chudobnými krajinami. Navyše, prianie globalizovat’ solidaritu nie je len otázkou prispôsobovania sa novým požiadavkám medzinárodnej situácie alebo zmenám v aplikovaní trhových síl, ale predovšetkým je odpoved’ou na naliehavé požiadavky Kristovho evanjelia." ${ }^{\text {"74 }}$

Podobne o nevyhnutnosti šírit globalizáciu svetovo hovoril aj Benedikt XVI. vo svojom príhovore k vtedajšiemu nastupujúcemu velvyslancovi Uruguaja pri Svätej stolici, ktorým bol Mario Juan Bosco Cayota Zappettini:

„V dnešných časoch obrovský problém chudoby a marginalizácie predstavuje naliehavú výzvu vládcom a tým, ktorí majú na starosti verejné inštitúcie. Na druhej strane, tzv. ,globalizačné procesy' vytvárajú nové možnosti, ale aj nové riziká, ktorým treba čelit’ v rámci väčšej súhry národov. Ide o príležitost’ na pokračovanie spriadania siete pochopenia a solidarity medzi národmi, a to bez toho, aby sme všetko redukovali do podoby komerčnej alebo pragmatickej výmeny; tam, kde je priestor pre ludské problémy každej oblasti." ${ }^{\text {75 }}$

O relatívne dobrej znalosti družstevného fungovania v prípade Františka svedčí nielen poskytnutie vyššie spomínaných povzbudení, ale aj prehlad, aký má v jednotlivých typoch družstiev, ktoré vo svojej reči vymenoval: od polnohospodárskych k tým, ktoré poskytujú bývanie bezdomovcom, od sociálnych k úverovým, od rybolovu k priemyslu, biznisu a spotrebným družstvám: „Som si dobre vedomý, že tento zoznam nie je úplný, ale je skôr užitočný, aby sme pochopili, aká vzácna je družstevnícka metóda, ktorá musí napredovat’ a byt’ kreatívna." ${ }^{76}$

dostupné na: https://w2.vatican.va/content/francesco/en/speeches/2015/september/documents/papa-francesco_ 20150912_banca-credito-cooperativo.html, citované 8. 12. 2015.

73 (c) FRANTIŠEK, Address of His Holiness Pope Francis to participants of the World Congress of Accountants, 14. 11. 2014 (on-line), dostupné na: https://w2.vatican.va/content/francesco/en/speeches/2014/november/documents/papa-francesco_20141114_congresso-mondiale-commercialisti.html, citované 9. 12. 2015.

74 () JÁN PAVOL II., Message of John Paul II on the occasion of the $17^{\text {th }}$ General Assembly of Caritas Internationalis, 04. 07. 2003 (on-line), dostupné na: https://w2.vatican.va/content/john-paul-ii/en/speeches/2003/july/documents/hf_jp-ii_spe_20030707_caritas-internationalis.html, citované 8. 12. 2015.

75 (c) BENEDIKT XVI., Address of His Holiness Pope Benedict XVI to H.E. Mr Mario Juan Bosco Cayota Zappettini, Ambassador of the Oriental Republic of Uruguay to the Holy See, 30. 06. 2006 (on-line), dostupné na: http://w2.vatican.va/content/benedict-xvi/en/speeches/2006/june/documents/hf_ben-xvi_spe_20060630_ambassador-uruguay.html, citované 8. 12. 2015. Viac o politických a etických dimenziách nadnárodnej (globálnej) solidarity pozri Janusz SALAMON (ed.), Solidarity Beyond Borders: Ethics in a Globalising World, Londýn: Bloomsbury Publishing, 2015.

76 ( ) FRANTIŠEK, Address of His Holiness Pope Francis to representatives of the Confederation of Italian Cooperatives. 
Fakt dôverného poznania problematiky družstevníctva potvrdzuje ešte aj jeho osobná spomienka, s ktorou sa František podelil vo svojom videoposolstve k účastníkom 3. ročníka Festivalu sociálnej náuky cirkvi v severotalianskej Verone v roku 2013, ktorý s heslom „Menej nerovnosti, viac rozdielnosti“ organizovali zväzy krestanských podnikatelov a družstevné nadácie a združenia pod patronátom Pápežskej rady pre spravodlivost' a pokoj (Iustitia et Pax). V polhodinovom posolstve pápež uviedol:

„Spomínam si, bol som mladík, mal som 18 rokov: bol rok 1945 a počul som svojho otca hovorit o krestanskom družstevníctve a od tej chvíle som sa nadchol pre tú myšlienku. Videl som, že toto je cesta. Je to predovšetkým cesta rovnosti, nie homogenity, ale rovnosti v rozdielnosti. Táto cesta trvá z ekonomického hladiska dlho. Spomínam si na otcovu úvahu: ide to síce pomaly, ale je to istá cesta (...).“77

Štvrtá rovina nastolená pápežom Františkom v jeho príhovore z februára 2015 je rovina budúcej úlohy družstiev. Už vo svojich vyššie spomínaných piatich povzbudeniach naznačil, akým smerom by sa družstevné hnutie mohlo uberat'. Zdôraznil tiež, že zmysel družstiev je aj tak trochu prorocký, zameraný na budúcnost. Otvorene sa postavil za hnutie „empresas recuperadas“, ako sa $\mathrm{v}$ španielčine označuje, čo znamená továrne, ktoré boli opustené ich vlastníkmi a obsadené pracujúcimi, ktorí v nich začali pôsobit ako noví vlastníci. Robotníci okupujú továrne, aby ich tak udržali pri živote: „Som fanúšikom empresas recuperadas, “ vyznal sa otvorene František. ${ }^{78}$ Nepriamo tak, podobne ako pred ním sv. Ján Pavol II., vyjadril sympatie k zamestnaneckej (spolu)účasti na vlastníctve a riadení podniku. Tento princíp, či skôr hnutie, je niekedy vnímané ako alternatíva voči kapitalizmu (so zachovaním princípu trhovej ekonomiky), inokedy je v rámci „širšej definície kapitalizmu, “79 označované za „trhový socializmus, v rámci ktorého pracujúci (...) participujú prostredníctvom zhromaždení alebo rád na rozhodovacom procese (...) organizácie a prijímajú podiel z jej výnosov“. 80

\section{Záver}

Týmto sa dostávame $\mathrm{k}$ záveru uvažovania o družstevníctve a jeho pozícii v rámci KSN, v porovnaní s mainstreamovým prístupom, ktorý reprezentujú OSN a EÚ. Jej jedinečnost' v porovnaní s Leninovými špecifickými pohladmi je taktiež zjavná. Z pohladu KSN je totiž pre družstevníctvo charakteristický jeho antropocentrický charakter, ako aj komunitaristická povaha.

Vo svojom vyššie spomínanom príhovore František zdôraznil, a to plne v súlade so svojimi predchodcami, že to bola už encyklika Leva XIII. Rerum novarum, ktorá spomína družstvá. Oficiálna katolícka náuka o družstvách sa teda spája s historickou tradíciou, vrátane dnes už zastaraného prístupu tzv. krestanskej solidaristickej školy, ktorú reprezentovali napríklad Antonín Pimper v Československu alebo Heinrich Pesch v Nemecku. ${ }^{81}$ Pápež František nám navyše pripomína, že

77 (c) FRANTIŠEK, Video-message of Pope Francis for the Third Festival of the social doctrine of the Church held in Verona, 21.-24. 11. 2013 (on-line), dostupné na: https://w2.vatican.va/content/francesco/en/messages/pont-messages/2013/documents/papa-francesco_20131121_videomessaggio-festival-dottrina-sociale.html, citované 27. 12. 2015.

78 () FRANTIŠEK, Address of His Holiness Pope Francis to representatives of the Confederation of Italian Cooperatives.

79 Dennis H. WRONG, Is Capitalism eternal?, Critical Review 1/2004, s. 26.

80 Tamže.

81 Antonín PIMPER, Křestanský solidarismus; Heinrich PESCH, Lehrbuch der Nationalökonomie, Freiburg im Breisgau: Herder, 19051923 (5 zväzkov). Viac o solidaristickom hnutí pozri napr. Joseph N. MOODY, Church and Society: Catholic Social and Political 
latinské slovo „cooperari“, stojace v základe slova družstevníctvo (niekedy nazývaného aj „kooperatíva“), znamená pracovat’ spolu, pomáhat’, prispievat' k dosiahnutiu ciela.

Preto František vyzval svojich poslucháčov, aby neboli spokojní so slovom „družstvo“ bez toho, aby mali na pamäti skutočného ducha spolupráce. Tým sa v jeho myslení potvrdzujú súčasné tendencie niektorých spoločenských vedcov, ktorí zdôrazňujú, že odcudzenie vlastné kapitalizmu by malo byt nahradené sociálno-ekonomickými vzṫahmi, ktoré podporujú formáciu „spoločnosti spolupráce“ a popularizujú termín družstvo ako „novú a vyššiu formu demokracie“. ${ }^{82}$

To, čo odlišuje prístup pápežov k družstevníctvu od mainstreamového prístupu, ktorý predstavuje EÚ je, že pápeži nekladú primárny dôraz na ekonomické benefity družstiev, ale vyzdvihujú budovanie komunity. Z pohladu katolíckej náuky slúžia družstvá na zlepšenie interpersonálnych vzt’ahov, na budovanie silného spoločenstva založeného na zdielaných hodnotách, ako aj na boj so sociálnou nespravodlivostou.

Bolo by však chybou chápat tento prístup v zmysle triednej jednoty, v akú veril Lenin. To, čo sa myslí pod spoločnými hodnotami, je v tomto prípade príslušnost' ku krestanstvu, zdielaný záväzok bratstva a vzájomná pomoc. Hlavným nástrojom v boji so sociálnou nespravodlivostou teda nie je triedny boj a politická revolúcia, ako to hlásal marxizmus, ale vzájomná spolupráca a ludské úsilie pracovat’ spoločne, pretože „ludská práca je účastou na Božom diele“. ${ }^{83}$

\title{
Idea družstevníctva zo spoločenskovednej perspektívy so zvláštnym dôrazom na katolícku sociálnu náuku
}

\begin{abstract}
Abstrakt
V článku objasňujem základné črty družstevníctva z pohladu spoločenských vied. Opísané sú jeho historické korene, zvlášt' v myslení Roberta Owena a V. I. Lenina, ako aj mainstreamový družstevnícky model, ako ho prezentuje OSN a Európska únia. Vzhladom na to, že učenie o úlohe družstevníckeho podnikania v súčasnej kapitalistickej ekonomike tvorí integrálnu súčast' katolíckej sociálnej náuky, zvláštny dôraz je kladený na učenie pápežov o družstvách.
\end{abstract}

Klúčové slová: družstvá, katolícka sociálna náuka, pápež František

\section{Kontakt na autora \\ PhDr. Marián Sekerák}

Univerzita Karlova v Praze

Fakulta sociálních věd, Institut politologických studií

U Kříže 8, 15800 Praha 5 - Jinonice

marian.sekerak@gmail.com 